\title{
New records and distribution map of Gold-striped Frog, Lithodytes lineatus (Schneider, 1799) (Anura, Leptodactylidae), in an ecotonal zone in Mato Grosso, Brazil
}

\author{
Eder Correa Fermiano ${ }^{1}$, Vancleber Divino Silva-Alves ${ }^{2 *}$, Matheus Oliveira Neves ${ }^{3}$, \\ Odair Diogo da Silva², Manoel dos Santos-Filho², Dionei José da Silva ${ }^{1,2}$ \\ 1 Programa de Pós-Graduação em Ambiente e Sistemas de Produção Agrícola, Universidade do Estado de Mato Grosso, \\ Tangará da Serra, MT, Brazil \\ 2 Programa de Pós-Graduação em Ciências Ambientais, Centro de Pesquisa de Limnologia, Biodiversidade, Etnobiologia do \\ Pantanal, Universidade do Estado de Mato Grosso, Cáceres, MT, Brazil \\ 3 Programa de Pós-Graduação em Ecologia e Conservação, Instituto de Biociências, Universidade Federal de Mato Grosso do \\ Sul, Campo Grande, MS, Brazil \\ * Corresponding author: vancleber.silva@unemat.br
}

\begin{abstract}
Lithodytes lineatus (Schneider, 1799) is a small, litter-dwelling frog widely distributed in the Amazon Ecoregion and some transitional areas between the Amazon and Cerrado. Here we report seven new records of this species in a transitional zone between Amazon, Chiquitano Dry Forest and Cerrado ecoregions in the state of Mato Grosso, Brazil. These are the southernmost records of the species, expanding its distribution in $320 \mathrm{~km}$ from the nearest record in Bolivia.
\end{abstract}

Keywords

Amphibians, Cerrado-Amazon ecotone, Chiquitano Dry Forest Ecoregion

Academic editor: Angele Martins | Received 31 May 2020 | Accepted 7 December 2020 | Published 5 January 2021

Citation: Fermiano EC, Silva-Alves VD, Neves MO, Silva-Diogo O, Santos-Filho M, Silva DJ (2021) New records and distribution map of Goldstriped Frog, Lithodytes lineatus (Schneider, 1799) (Anura, Leptodactylidae), in an ecotonal zone in Mato Grosso, Brazil. Check List 17 (1): 7-11. https://doi.org/10.15560/17.1.7

\section{Introduction}

The family Leptodactylidae has 220 currently recognized species distributed in the Neotropics, with 161 of them occurring in Brazilian territory (Segalla et al. 2019; Frost 2020). In Brazil, the family is represented by three subfamilies, with Leptodactylinae representing the most diverse taxon and containing 75 species allocated to the genera Adenomera (16 spp.), Hydrolaetare (3 spp.), Leptodactylus (55 spp.), and Lithodytes (1 sp.) (Segalla et al. 2019).
Lithodytes Fitzinger, 1843 is a monotypic genus which was has previously considered a subgenus of Leptodactylus (Frost et al. 2006). It was elevated to a full genus by Pyron and Wiens (2011). Lithodytes lineatus (Schneider, 1799) is a small litter-dwelling frog (snout-vent length [SVL] 34-45 $\mathrm{mm}$ in males and $44-56 \mathrm{~mm}$ in females) which presents a singular association with colonies of leaf-cutting ants of the genus Atta and uses the colonies as shelter and a breeding location (Rodriguez and 
Duellman 1994; Lima et al. 2006; Bernarde 2007; Barros et al. 2016). Lithodytes lineatus occurs in the Amazon region of Bolivia, Brazil, Ecuador, French Guiana, Peru, Suriname, and Venezuela (Harvey et al. 1998; La Marca et al. 2010; Barrios-Amorós et al. 2019; Frost 2020).

In Brazil, L. lineatus has been reported for the states of Amazonas (Lima et al. 2006; França and Venâncio 2010), Acre (Bernarde et al. 2011; 2013), Pará (Bernardo et al. 2012), Rondônia (Bernarde 2007; Bernarde and Macedo 2008; Bernarde and Kokubum 2009), the northern portion of Mato Grosso (São Pedro et al. 2009; Noronha et al. 2015) and Maranhão (Freitas et al. 2014). There are also records of this species from transition zones between the Amazon and Cerrado ecoregions (Tropical and Subtropical Moist Broadleaf Forests and Tropical and Subtropical Grasslands, Savannas and Shrublands biomes, respectively) in the states of Mato Grosso (Bitar et al. 2012) and Tocantins (Cintra et al. 2014; Thaler et al. 2020), and in the Chiquitano Dry Forest Ecoregion (Tropical and Subtropical Dry Broadleaf Forests biome) in Bolivia (Harvey et al. 1998).

In the present study, we report seven new records of L. lineatus from Mato Grosso state, Brazil, where we found it in the Chiquitano Dry Forest Ecoregion, which is a transition zone of the Amazon and Cerrado. Additionally, we provide an updated distribution map with the new records and localities from the literature which lie outside the distribution of the species as shown by La Marca et al. (2010).

\section{Methods}

We collected the specimens using 126 sets of pitfall traps in 21 forest fragments from 2002 to 2004. One record was based on a specimen housed in the Amphibian Collection of Museu Nacional, Universidade Federal do Rio de Janeiro, state of Rio de Janeiro, Brazil (MNRJ). The fragments are inserted in a pasture matrix, in the microbasins of the Jauru and Cabaçal rivers, tributaries of the Paraguay river, in southwestern Mato Grosso. The local vegetation is classified as Seasonal Submontane Semideciduous Forest and is part of the Chiquitano Dry Forest Ecoregion (Olson et al. 2001; IBGE 2004; Power et al. 2016). According to the Köppen classification, the climate is Aw type with average temperatures ranging from 24 to $26{ }^{\circ} \mathrm{C}$ and precipitation from 1300 to 1600 mm annually (Alvares et al. 2013).

In each fragment inspected, we installed six series of pitfall traps (Cechin and Martins 2001). The first series was installed on the pasture, $50 \mathrm{~m}$ from the edge of the fragment. The second on the edge and the next, successively, every $50 \mathrm{~m}$ inside the fragment until $200 \mathrm{~m}$. Each series consisted of five buckets, each with a volume of $24 \mathrm{~L}$, buried in the ground. The buckets were spaced 10 $\mathrm{m}$ apart in a line and connected by an $80 \mathrm{~cm}$ high plastic canvas guide fence. We opened the trap sets for 10 consecutive days in each forest fragment and inspected the trap sets daily each morning.
The specimens were euthanized with the administration of topical lidocaine gel $(2 \%)$ inside the mouth or ventral and inguinal region. We housed the voucher specimens in the Coleção Herpetológica do Centro de Pesquisa de Limnologia, Biodiversidade, Etnobiologia do Pantanal (CELBE) of the Universidade do Estado de Mato Grosso. The collection licenses were granted by Instituto Brasileiro de Meio Ambiente e dos Recursos Naturais Renováveis (no. 033/02, 004/03, and 057/04).

The specimens of L. lineatus were identified based on Rodriguez and Duellman (1994) and Lima et al. (2006). We measured the SVL of the specimens using digital calipers (Digimess 100.176BL).

\section{Results}

\section{Lithodytes lineatus (Schneider, 1799)}

We collected six individuals of $L$. lineatus in Chiquitano Dry Forest, transition zone of the Amazon Ecoregion with the Cerrado, in the municipalities of Araputanga, Indiavaí, Jauru, and São José dos Quatro Marcos southwestern region of the Mato Grosso state. Among the six individuals, only one (MZT 0160) was collected at the fragment edge, whereas the others were collected at least $50 \mathrm{~m}$ into the forest fragment, with no records in the pasture matrix. We collected one individual in the area of influence of a small hydroelectric power plant in the municipality of Jauru. Four records were made during the rainy season and two during the dry season. The seventh record was obtained from the Amphibian Collection of Museu Nacional, Universidade Federal do Rio de Janeiro, state of Rio de Janeiro, Brazil (MNRJ 87248) collected in the municipality of Lambari D'Oeste, Mato Grosso in 2013 (Fig. 1).

New records. $\mathrm{BRAZIL} \cdot 1$ adult $\odot, \mathrm{SVL}=48.4 \mathrm{~mm}$; Mato Grosso, Araputanga municipality, Jauru river basin, Seasonal Semideciduous Submontane Forest, Chiquitano Dry Forest Ecoregion, Amazon rainforest and Cerrado Ecotone; 15²3'21"S, 058 24'54"W; 310 m a.s.l.; 11 Feb. 2002; Dionei José da Silva and Manoel dos Santos-Filho leg.; collected at the edge of a 97 ha fragment; MZT 0160. - 1 adult 9, SVL = $47.62 \mathrm{~mm}$; Mato Grosso, São José dos Quatro Marcos municipality, Cabaçal river basin, Seasonal Semideciduous Submontane Forest, Chiquitano Dry Forest Ecoregion, Amazon rainforest and Cerrado Ecotone; 15²2'37"S, 058 03'50"W; 176 m a.s.l.; 25 Jan. 2003; Dionei José da Silva and Manoel dos Santos-Filho leg.; collected $100 \mathrm{~m}$ from the edge of a 152 ha fragment; MZT 0256 (Fig. 2). 1 unidentified sex, SVL $=44.40$ $\mathrm{mm}$; Mato Grosso, Jauru municipality, Jauru river basin, Chiquitano Dry Forest Ecoregion, Amazon rainforest and Cerrado Ecotone; $15^{\circ} 12^{\prime} 42^{\prime \prime} \mathrm{S}, 058^{\circ} 43^{\prime} 54^{\prime \prime} \mathrm{W} ; 388 \mathrm{~m}$ a.s.1.; 07 May 2003; Dionei José da Silva and Manoel dos Santos-Filho leg.; collected in the area of influence of the Jauru Hydroelectric Power Plant; MZT 0482. • 1 juvenile SVL $=27.71 \mathrm{~mm}$; Mato Grosso, São José dos 


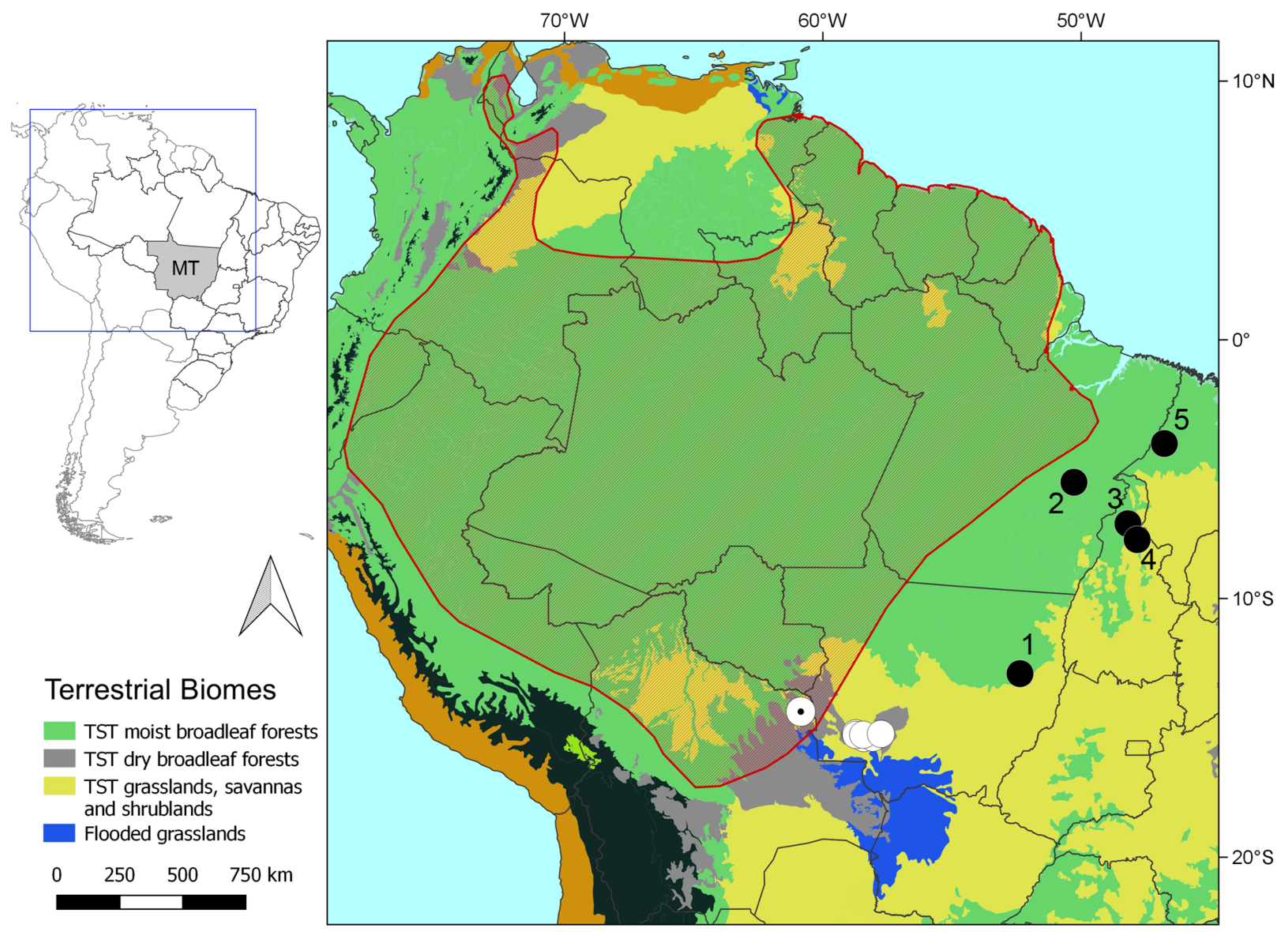

Figure 1. Distribution map of Lithodytes lineatus in South America. Red polygon: distribution of the species according to La Marca et al. (2010). White circles: new records in Araputanga, Jauru, Lambari D'Oeste, Indiavaí, and São José dos Quatro Marcos municipalities, southwestern Mato Grosso. White circle with dot: nearest previous record, in Noel Kempff Mercado National Park, in Bolivia (Harvey et al. 1998). Black circles: other records from the literature outside distribution of the species according to La Marca et al. (2010) and in Amazon-Cerrado transitional areas: (1) Querência municipality (MT) (Bitar et al. 2012), (2) Marabá and São Félix do Xingu municipalities (Pará) (Bernardo et al. 2012), (3) Araguaína municipality (Tocantins) (Thaler et al. 2020); (4) Filadélfia municipality (Tocantins) (Cintra et al. 2014), and (5) Bom Jardim municipality (Maranhão) (Freitas et al. 2013). Abbreviations: MT = Mato Grosso state; and TST = Tropical and Sub-Tropical. The terrestrial biomes are adapted from Olson et al. (2001).

Quatro Marcos municipality, Cabaçal river basin, Seasonal Semideciduous Submontane Forest, Chiquitano Dry Forest Ecoregion, Amazon rainforest and Cerrado Ecotone; $15^{\circ} 22^{\prime} 37^{\prime \prime} \mathrm{S}, 058^{\circ} 03^{\prime} 50^{\prime \prime} \mathrm{W} ; 176 \mathrm{~m}$ a.s.1.; $28 \mathrm{Aug}$. 2003; Dionei José da Silva and Manoel dos Santos-Filho leg.; collected $200 \mathrm{~m}$ from the edge of a 152 ha fragment; MZT 0493. 1 adult +, $\mathrm{SVL}=46.17 \mathrm{~mm}$; Mato Grosso, Indiavaí municipality, Jauru river basin, Seasonal Semideciduous Submontane Forest, Chiquitano Dry Forest Ecoregion, Amazon rainforest and Cerrado Ecotone; $15^{\circ} 16^{\prime} 13^{\prime \prime} \mathrm{S}, 058^{\circ} 42^{\prime} 46^{\prime \prime} \mathrm{W} ; 247 \mathrm{~m}$ a.s.l.; 24 Jan. 2004; Dionei José da Silva and Manoel dos Santos-Filho leg.; collected $200 \mathrm{~m}$ from the edge of a 100 ha fragment; MZT 0640. 1 juvenile, $S V L=25.07 \mathrm{~mm}$; Mato Grosso, Araputanga municipality, Jauru river basin, Seasonal Semideciduous Submontane Forest, Chiquitano Dry Forest Ecoregion, Amazon rainforest and Cerrado Ecotone; $15^{\circ} 15^{\prime} 48^{\prime \prime} \mathrm{S}, 058^{\circ} 26^{\prime} 17^{\prime \prime} \mathrm{W} ; 334$ m a.s.l.; 25 Jan. 2004; Dionei José da Silva and Manoel dos Santos-Filho leg.; collected $200 \mathrm{~m}$ from the edge of a 4,739 ha fragment; MZT 0812. - 1 unidentified sex; Mato Grosso, Lambari D'Oeste municipality, Jauru river basin, Chiquitano
Dry Forest Ecoregion, Amazon and Cerrado Ecotone; $15^{\circ} 13^{\prime} 52.00^{\prime \prime} \mathrm{S}, 057^{\circ} 45^{\prime} 02.02^{\prime \prime} \mathrm{W}$; 24 Nov. 2013; collector not specified; MNRJ 87248.

Identification. We identified the specimens as $L$. lineatus based on the following main diagnostic characters. The dorsum skin is slightly spiculated and the color is black with two dorsolateral, yellow or cream-colored bands (Fig. 2A) that extends from the snout to the flanks (Rodriguez and Duellman 1994; Lima et al. 2006); the ventral surface (Fig. 2B) is smooth and grayish-brown with cream-colored spots (Rodriguez and Duellman 1994). Large red spots are present in the inguinal and axillary regions, and even on the thighs (Rodriguez and Duellman 1994). The legs are brown with transverse bars on their posterior part (Lima et al. 2006).

According to Rodriguez and Duellman (1994), juvenile $L$. lineatus can be misidentified with the dendrobatid frog Allobates femoralis (Boulenger, 1884). However, $A$. femoralis differs from L. lineatus in having a half-moonshaped red spot on the thigh, a yellow spot at the base of the arm, a white sideband that extends from the labial to the inguinal regions, and a white belly with black 

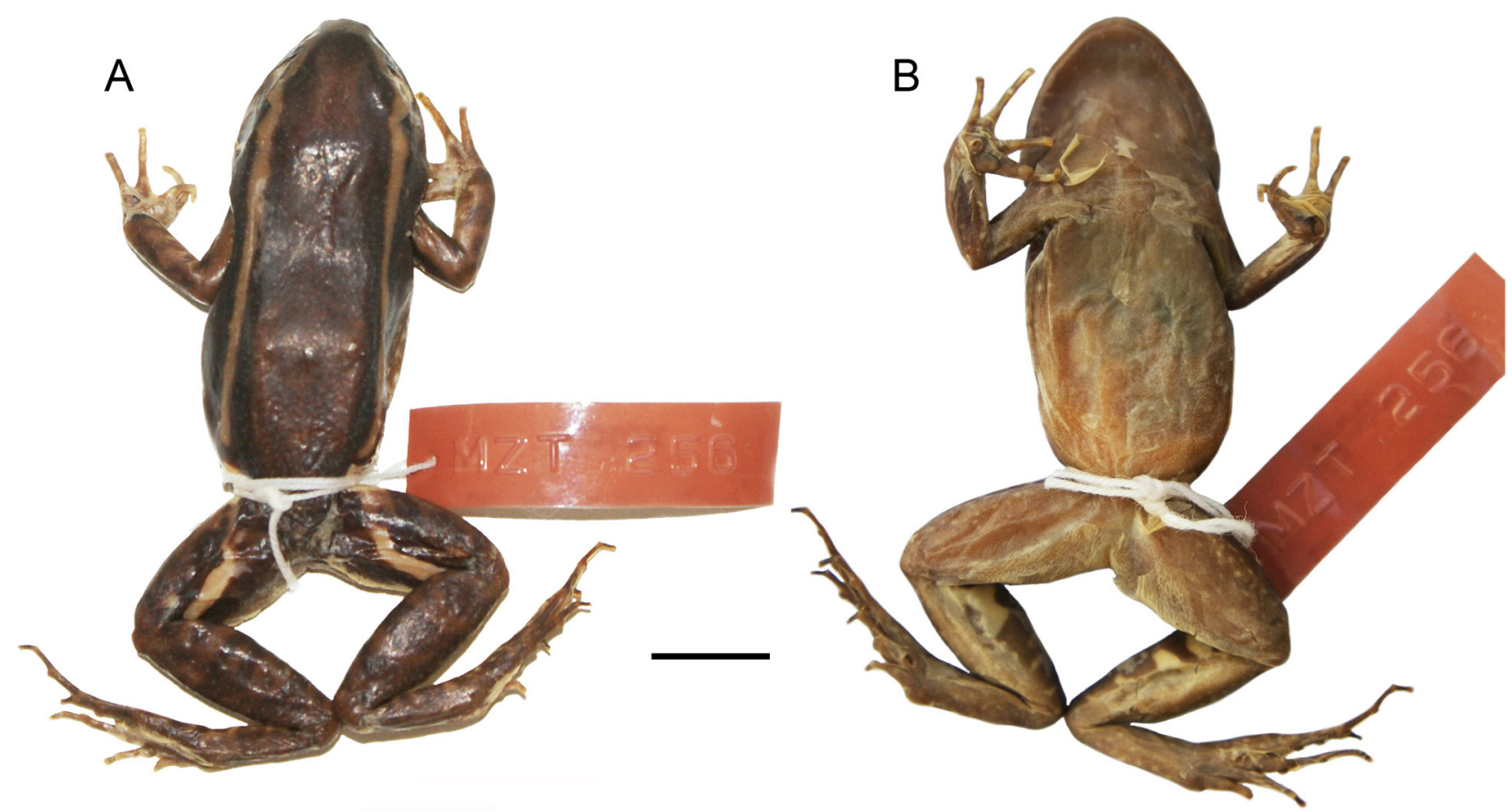

Figure 2. Lithodytes lineatus from the municipality of São José dos Quatro Marcos, southwestern Mato Grosso, Brazil (MZT 0256). A. Dorsal view. B. Ventral view. Scale bar $=1 \mathrm{~cm}$.

spots (Rodriguez and Duellman 1994; Lima et al. 2006; Amézquita et al. 2009).

\section{Discussion}

Lithodytes lineatus is widely distributed along the Amazon, and it is also recorded in transition zones of the Amazon and Cerrado ecoregions (Barrio-Amorós et al. 2019; Frost 2020; Thaler et al. 2020). Although this species has been recorded from Mato Grosso, until now it was only known from the typically Amazonian areas in the northern part of the state (São-Pedro et al. 2009; Noronha et al. 2015) and from transition zones in the northeastern of the state (Bitar et al. 2012). In the present study we report new records in the Chiquitano Dry Forest Ecoregion in southwestern Mato Grosso.

Our new records of $L$. lineatus from the municipalities of Jauru, Indiavaí, Lambari D’Oeste, Araputanga, and São José dos Quatro Marcos extend this species' distribution by $320 \mathrm{~km}$ from the previously known record in Noel Kempff Mercado National Park, eastern Bolivia (Harvey et al. 1998). The record from Araputanga represents the southernmost occurrence of this species ( Fig. 1). Our new records expand the known distribution of $L$. lineatus to the south outside of the the species' distribution according to La Marca et al. (2010).

We found specimens of L. lineatus only at the edge and within the forest fragments, but not in adjacent pastures, where we also placed traps. Our results reinforce the preferences of this species for forest environments and the structures made available by the forest, such as the presence of litter (Rodriguez and Duellman 1994; Bernarde and Macedo 2008; Bernarde and Kokubum 2009). In this sense, the conversion of native vegetation to areas of crops and pasture in the region of the new records (Silva et al. 2014; Fermiano et al. 2020) may represent an important local threat to the species, as also observed by Bernarde and Kokubum (2009). In addition, one of the records (MZT 0482) occurred within the area influenced by the Jauru Hydroelectric Power Plant, which reinforces the need for greater attention to the conservation of the adjacent forest remnants as a way to guarantee the local viability of this species.

\section{Acknowledgements}

We are grateful to the Coordenação de Aperfeiçoamento de Pessoal de Nível Superior for the Master's scholarship granted to ECF, VDSA, and ODS. We thank the curators of the Museu Nacional for their support and permission to examine the specimen in its care. We also thank Ana Paula Dalbem Barbosa for reviewing the English, and the subject editor and reviewers for their important contributions and comments which helped to improve this manuscript.

\section{Authors' contribution}

DJS, MSF collected the specimens. MON visited the Museu Nacional. ECF and VDSA identified the specimens. ECF, VDSA, ODS wrote the manuscript and MON and DJS reviewed the manuscript text and complemented it with additional information.

\section{References}

Alvares CA, Stape JL, Sentelhas PC, De Moraes G, Leonardo J, Sparovek G (2013) Köppen's climate classification map for Brazil. Meteorologische Zeitschrift 22 (6): 711-728. https://doi.org/ 
$10.1127 / 0941-2948 / 2013 / 0507$

Amézquita A, Lima AP, Jehle R, Castellanos I, Ramos Ó, Crawford AJ, Gasser H, Hödl W (2009) Calls, colours, shape, and genes: a multi-trait approach to the study of geographic variation in the Amazonian frog Allobates femoralis. Biological Journal of the Linnean Society 98 (4): 826-838. https://doi.org/10.1111/j.10958312.2009.01324.x

Barrio-Amorós CL, Rojas-Runjaic FJM, Señaris JC (2019) Catalogue of the amphibians of Venezuela: illustrated and annotated species list, distribution, and conservation. Amphibian and Reptile Conservation 13 (1): 1-198.

Barros A de L, López-Lozano JL, Lima AP (2016) The frog Lithodytes lineatus (Anura: Leptodactylidae) uses chemical recognition to live in colonies of leaf-cutting ants of the genus Atta (Hymenoptera: Formicidae). Behavioral Ecology and Sociobiology 70 (12): 2195-2201. https://doi.org/10.1007/s00265-016-2223-y

Bernarde PS (2007) Ambientes e temporada de vocalização da anurofauna no Município de Espigão do Oeste, Rondônia, Sudoeste da Amazônia: Brasil (Amphibia: Anura). Biota Neotropica 7 (2): 87 92. https://doi.org/10.1590/S1676-06032007000200010

Bernarde PS, de Albuquerque S, de Miranda DB, Turci LCB (2013) Herpetofauna da floresta do baixo rio Moa em Cruzeiro do Sul, Acre-Brasil. Biota Neotropica 13 (1): 219-244. https://doi. org/10.1590/S1676-06032013000100023

Bernarde PS, Kokubum MNDC (2009) Seasonality, age structure and reproduction of Leptodactylus (Lithodytes) lineatus (Anura, Leptodactylidae) in Rondônia state, southwestern Amazon, Brazil. Iheringia Série Zoologia 99 (4): 368-372. https://doi.org/10.1590/ S0073-47212009000400005

Bernarde PS, Macedo LC (2008) Impacto do desmatamento e formação de pastagens sobre a anurofauna de serapilheira em Rondônia. Iheringia Série Zoologia 98 (4): 454-459.

Bernarde PS, Machado RA, Turci LCB (2011) Herpetofauna da área do Igarapé Esperança na Reserva Extrativista Riozinho da Liberdade, Acre-Brasil. Biota Neotropica 11 (3): 117-144. https://doi. org/10.1590/S1676-06032011000300010

Bernardo PH, Guerra-Fuentes RA, Matiazzi W, Zaher H. (2012). Checklist of amphibians and reptiles of Reserva Biológica do Tapirapé, Pará, Brazil. Check List 8 (5): 839-846. https://doi.org/ $10.15560 / 8.5 .839$

Bitar YOC, Pinheiro LPC, Abe OS, Santos-Costa MC (2012) Species composition and reproductive modes of anurans from a transitional Amazonian forest, Brazil. Zoologia 29 (1): 19-26. https:// doi.org/10.1590/S1984-46702012000100003

Cechin SZ, Martins M (2000) Eficiência de armadilhas de queda (pitfall traps) em amostragens de anfíbios e répteis no Brasil. Revista Brasileira de Zoologia 17 (3): 729-740. https://doi.org/10.1590/ S0101-81752000000300017

Cintra CED, da Silva HLR, Junior NJS (2014) First record of Lithodytes lineatus (Schneider, 1799) (Anura: Leptodactylidae) in the state of Tocantins, ecotone zone Amazon-Cerrado biomes, with notes on its natural history. Herpetology Notes 7: 179-184.

Fermiano EC, Silva-Alves VD, Silva-Diogo O, Seba MFR, AraujoGoebel LG, Santos-Filho M, Silva DJ (2020) New records of Apostolepis kikoi Santos et al., 2018 (Serpentes, Dipsadidae) in the state of Mato Grosso, Central-West Brazil. Check List 16 (4): 1049-1053. https://doi.org/10.15560/16.4.1049

França FGR, Venâncio NM (2010) Reptiles and amphibians of a poorly known region in southwest Amazonia. Biotemas 23 (3) 71-84. https://doi.org/10.5007/2175-7925.2010v23n3p71

Freitas MA, Farias T, Sousa SO, Vieira RS, de Moura GJB, Dias IR (2014) First record of Lithodytes lineatus (Schneider, 1799) (Anura: Leptodactylidae) in northeastern Brazil. Check List 10 (3): 615-617. https://doi.org/10.15560/10.3.615

Frost DR (2020) Amphibian species of the world: an online reference. Version 6.0. https://amphibiansoftheworld.amnh.org/index. php. American Museum of Natural History, New York, USA. Ac- cessed on: 2020-12-03.

Frost DR, Grant T, Faivovich J, Bain RH, Haas A, Haddad CFB, De Sá RO, Channing A, Wilkinson M, Donnellan SC, Raxworthy CL, Faivovich J, Blotto BL, Moler P, Drewes RC, Nussbaum RA, Lynch JD, Green DM, Wheeler WC (2006) The Amphibian Tree of Life. Bulletin of the American Museum of Natural History 2006 (297): 1-291. https://doi.org/10.1206/0003-0090(2006) 297[0001:tatol]2.0.co;2

Harvey MB, Aparicio J, Cortez C, González L, Guerra JF, Montano ME, Pérez ME (1998) Reptiles and amphibians of Parque Nacional Noel Kempff Mercado. In: Killeen TJ, Schulenberg TS (Eds) A biological assessment of Parque Nacional Noel Kempff Mercado, Bolivia. RAP Working Papers 10, Conservation International, Washington, DC, USA, 348-355.

IBGE (Instituto Brasileiro de Geografia e Estatística) (2004) Mapa de biomas do Brasil: primeira aproximação. ftp://geoftp.ibge.gov. br/informacoes_ambientais/estudos_ambientais/biomas/mapas/ biomas5000mil.pdf. Acessed on: 2020-02-23

La Marca E, Azevedo-Ramos C, Coloma LA, Ron S, Hardy J (2010) Lithodytes lineatus. The IUCN Red List of threatened species 2010: e.T57177A11580398.https://doi.org/10.2305/iucn.uk.2010-2.rlts.t5 7177a11580398.en. Accessed on: 2020-05-27

Lamar WW, Wild ER (1995) Comments on the natural history of Lithodytes lineatus (Anura: Leptodactylidae), with description of the tadpole. Herpetological Natural History 3: 135-142.

Lima AP, Magnusson WE, Menim M, Erdtmann LK, Rodrigues DJ, Keller C, Hödl W (2006) Guia de Sapos da Reserva Adolpho Ducke - Amazônia Central. Áttema Design Editorial, Manaus, Brazil, 168 pp.

Noronha JC, Lima MM, Velasquez CL, Almeida EJ, Barros AB, Rodrigues DJ (2015) Update of anurans [sic] species of São Nicolau Farm, Mato Grosso, Brazil. Scientific Electronic Archives 8 (1): 15-25.

Olson DM, Dinerstein E, Wikramanayake ED, Burgess ND, Powell GVN, Underwood EC, D'amico JA, Itoua I, Strand HE, Morrison JC, Loucks CJ, Allnutt TF, Ricketts TH, Kura Y, Lamoreux JF, Wettengel WW, Hedao P, Kassem KR (2001) Terrestrial ecoregions of the world: a new map of life on Earth: a new global map of terrestrial ecoregions provides an innovative tool for conserving biodiversity. BioScience 51 (11): 933-938. https://doi.org/ 10.1641/0006-3568(2001)051[0933:teotwa]2.0.co;2

Power MJ, Whitney BS, Mayle FE, Neves DM, de Boer EJ, Maclean KS (2016) Fire, climate and vegetation linkages in the Bolivian Chiquitano seasonally dry tropical forest. Philosophical Transactions of the Royal Society: Biological Sciences 371: 1-11. https:// doi.org/10.1098/rstb.2015.0165

Pyron A, Wiens JJ (2011) A large-scale phylogeny of Amphibia including over 2,800 species, and a revised classification of extant frogs, salamanders, and caecilians. Molecular Phylogenetics and Evolution 61 (2): 543-583. https://doi.org/10.1016/j.ympev.2011.06.012

Rodríguez LO, Duellman WE (1994) Guide the frogs of the Iquitos region Peru, Amazon Peru. Natural History Museum, University of Kansas, Lawrence, KS, USA, 80 pp.

São-Pedro VA, Costa HC, Feio RN (2009) A herpetofauna da AHE Dardanelos, Aripuanã, Mato Grosso. Universidade Federal de Viçosa, Viçosa, Brazil, 42 pp.

Segalla MV, Caramaschi U, Cruz CAG, Garcia PCA, Grant T, Haddad CFB, Santana DJ, Toledo LF, Langone JA (2019) Brazilian amphibians: list of species. Herpetologia Brasileira 8 (1): 65-96.

Silva DJ, Santos-Filho M, Canale GR (2014) The importance of remnant native vegetation of Amazonian Submontane Forest for the conservation of lizards. Brazillian Journal of Biology 74 (3): 523 528. http://doi.org/10.1590/bjb.2014.0095

Thaler R, Folly H, Fadel R, Alves-da-Silva L, Mângia S, Santana DJ (2020). New records of Lithodytes lineatus (Anura: Leptodactylidae) in the Cerrado-Amazon transition. Caldasia 42 (1): 157-160. https://doi.org/10.15446/caldasia.v42n1.77257 